\title{
Frequency and antimicrobial susceptibility of Staphylococcus pseudintermedius in dogs with otitis externa
}

\author{
Carolina Boesel Scherer ${ }^{1}$ Larissa Silveira Botoni ${ }^{1}$ Fernanda Morcatti Coura $^{2}$ \\ Rodrigo Otávio Silva ${ }^{2}$ - Rafael Dantas dos Santos ${ }^{3}$ \\ Marcos Bryan Heinemann ${ }^{4}$ Adriane Pimenta Costa-Val ${ }^{1 *}$
}

${ }^{1}$ Departamento de Clínica e Cirurgia Veterinárias (DCCV), Escola de Veterinária (EV), Universidade Federal de Minas Gerais (UFMG), Belo Horizonte, MG, Brasil. E-mail: adriane@ufmg.br. "Corresponding author.

${ }^{2}$ Departamento de Medicina Veterinária Preventiva (DMVP), Escola de Veterinária (EV), Universidade Federal de Minas Gerais (UFMG), Belo Horizonte, MG, Brasil.

${ }^{3}$ Empresa Brasileira de Pesquisa Agropecuária (EMBRAPA), Semiárido, Aracaju, SE, Brasil.

${ }^{4}$ Departamento de Medicina Veterinária Preventiva e Saúde Animal, Faculdade de Medicina Veterinária (FMV), Universidade de São Paulo (USP), São Paulo, SP, Brasil.

ABSTRACT: Infections by Staphyloccocus pseudintermedius in the skin of dogs have been object of studies, since such microorganisms often present multiple resistance to antibiotics. This study aimed to identify and evaluate the antimicrobial susceptibility of Staphylococcus pseudintermedius (SP) strains isolated from dogs with otitis. Swabs from both ears of 52 dogs with otitis $(n=104)$ were included. Bacteria were cultured using Muller-Hinton agar (supplemented with 5\% equine blood and incubated at $37^{\circ} \mathrm{C}$ for 24 to 48 hours. All colonies underwent biochemical evaluation for identification of staphylococci. The identity of colonies as SP was confirmed by polymerase chain reaction. The antimicrobial susceptibility of SP strains was evaluated by disk diffusion. The presence of the gene mecA was evaluated in all SP isolates by PCR. Forty-four SP strains were isolated from swabs of 31 dogs (31/52, 59.6\%). Seventy-five percent of the strains were susceptible to cephalexin and $93.2 \%$ to amoxicillin plus clavulanic acid. Less than $23 \%$ of the strains were susceptible to penicillin. For non-beta-lactam antimicrobials, $63.6 \%$ of the strains showed resistance to sulfamethoxazole-trimethoprim, $61.4 \%$ to tetracycline, and 38 , $64 \%$ to enrofloxacin. Aminoglycoside resistance rate was $27.3 \%$ for gentamicin. Resistance to oxacillin in vitro was detected in 13 of the 44 strains (29, $55 \%$ ). A total of 12 strains (27.3\%) were positive for mecA gene and five of these 12 strains were susceptible to in vitro oxacillin. Twenty-six (59, 1\%) strains were resistant to three or more classes of antimicrobials, and classified as multi resistant. Our results showed high frequency of SP and multi resistant isolates to antimicrobials commonly used in veterinary.

Key words: $\operatorname{dogs}$, MRSP, methicillin-resistant staphylococcus, otitis.

Frequência e sensibilidade antimicrobiana de Staphylococcus pseudintermedius isolados de cães com otite externa

RESUMO: Infecções por Staphyloccocus pseudintermedius (SP) na pele de cães tem sido objeto de estudos, uma vez que esses microrganismos geralmente apresentam resistência múltipla à antibióticos. Este estudo teve como objetivo identificar e avaliar a susceptibilidade antimicrobiana das cepas de SP isoladas de cães com otite. Amostras de ambas orelhas de 52 cães com otite ( $n=104)$ foram incluidas. As bactérias foram cultivadas em ágar Muller-Hinton suplementado com $5 \%$ de sangue equino e incubadas a $37^{\circ} \mathrm{C}$ por 24 a $48 \mathrm{~h}$. Todas as colônias foram submetidas à avaliação bioquímica para identificação de estafilococos. A identificação das colônias como SP foi confirmada pela reação em cadeia da polimerase. A susceptibilidade antimicrobiana das cepas SP foi avaliada pela técnica de difusão em disco. A presença do gene mecA foi avaliada em todos os isolados de SP por PCR. 44 estirpes de SP foram isoladas de 31 cães (31/52, 59,6\%). 75\% das cepas foram suscetiveis a cefalexina e 93,2\% à amoxicilina mais ácido clavulânico. Menos de 23\% das estirpes eram suscetíveis à penicilina. Para antimicrobianos não beta-lactâmicos, 63,6\% apresentaram resistência ao sulfametoxazol-trimetoprim, 61,4\% à tetraciclina e 38,64\% à enrofloxacina. A frequência de resistência a aminoglicosídeos foi de 27,3\% para gentamicina. A resistência a oxacilina in vitro foi detectada em 13 das 44 estirpes (29,55\%). Um total de 12 amostras (27,3\%) foram positivas para mecA, cinco das quais foram suscetiveis à oxacilina na difusão em disco. 26 amostras (59,1\%) foram resistentes a três ou mais classes de antimicrobianos e classificadas como multirresistentes. Nossos resultados mostram elevada frequência de isolados SP e multiresistentes para os antimicrobianos comumente usados em veterinária. Palavras-chave: cães, MRSP, otite, Staphylococcus resistente a meticilina.

\section{INTRODUCTION}

Staphylococcus pseudintermedius is the leading cause of pyoderma and otitis externa in dogs, and is ultimately associated with urinary tract infections (VAN DUIJKEREN et al., 2011). Otitis disease affects nearly $20 \%$ of dogs admitted to veterinary clinics (COLE et al., 2006; SANCHEZ 
et al., 2011). Multiple antibiotic resistance is rapidly emerging in $S$. pseudintermedius, limiting the treatment options available (ROBERTS et al., 2014).

Methicillin resistance in staphylococci is commonly associated with the presence of the mecA gene. mecA encodes an altered penicillinbinding protein 2a (PBP2a) (FRANK \& LOEFFLER, 2012) and confers resistance to all beta-lactam antibiotics, including penicillins, cephalosporins, and carbapenems (KANIA et al., 2004; VAN DUIJKEREN et al., 2011; PRIYANTHAet al., 2016). In addition, methicillin-resistant $S$. pseudintermedius (MRSP) strains are commonly resistant to several other classes of non-beta-lactam antibiotics, including aminoglycosides, quinolones, macrolides, phenicols, sulfonamides, and tetracyclines (PAPICH, 2012).

Recent studies have shown that the incidence of MRSP is increasing in dogs (KASAI et al., 2016, PRIYANTHA et al., 2016). In Brazil, a high incidence of MRSP in dogs with pyoderma has been reported over the last few years (LOPES et al., 2015; BOTONI et al., 2016; BOURGUIGNON et al., 2016). Moreover, this microorganism has been increasingly implicated in human infections (SOMAYAJI et al., 2016; ROBB et al., 2017).

Despite the known importance of MRSP in companion animals and humans in other countries, few studies have been performed in Brazil. Moreover, studies regarding the prevalence of this microorganism in otitis and its antimicrobial resistance profile are even less common in the literature. Therefore, the purpose of this research was to determine the frequency of S. pseudintermedius in dogs diagnosed with otitis, and the antimicrobial susceptibility of the strains to several antibiotics, including methicillin, and to screen for the presence of the $m e c A$ gene.

\section{MATERIALS AND METHODS}

Fifty-two dogs of different breeds were selected from the Department of Dermatology at the Veterinary Hospital of the Universidade Federal de Minas Gerais (UFMG). Dogs were examined by veterinarians for the clinical diagnosis of otitis externa. All dogs used in the study had two or more clinical signs of otitis externa: pain; head shaking; itching; erythema; excoriations; hyperkeratosis; hyperpigmentation; partial or total ear canal stenosis; changes in color, odor, appearance and/or quantity of ear discharge; and positive coccoid bacteria by cytology. This experiment was approved by the Ethics Committee on Animal Use of UFMG under protocol number 246/2013.
Swabs from the horizontal channel of the external ear canal were collected from both ears, totaling 104 swabs. Samples were plated onto Muller-Hinton agar (Difco Laboratories, EUA) supplemented with 5\% equine blood and incubated at $37^{\circ} \mathrm{C}$ for 24 to $48 \mathrm{~h}$. All colonies underwent biochemical evaluation for identification of staphylococci, as previously described by QUINN et al. (2011) and BANNOEHR \& GUARDABASSI (2012). Biochemical examinations analyzed catalase, oxidase, coagulase, and urease production, carbohydrate fermentation (mannitol, sucrose, and trehalose), arginine production, Voges Proskauer (for acetoin production), and response to polymyxin $\mathrm{B}$.

Strains identified as belonging to the Staphylococcus genus were subjected to polymerase chain reaction (PCR) to amplify a 430-bp portion of the nuc gene locus to confirm their identity as $S$. pseudintermedius (SASAKI et al., 2010). Primers used for this analysis were: inf 5'CATGTCATATTATTGCGAATGA3', and inR3 5' AGGACCATCACCATTGACATATTGAAACC3'. Amplicons were separated by electrophoresis on a $1.5 \%$ agarose gel with a $1-\mathrm{kb}$ molecular marker (ThermoScientific ${ }^{\mathbb{B}}$ Waltham, Massachusetts, USA). S. pseudintermedius MRSP 3279, a reference strain previously used in other studies (BANNOEHR et al, 2009; BOURGUIGNON et al., 2016) were used as positive controls and amplification of sterile water served as a negative control.

The antimicrobial susceptibility of $S$. pseudintermedius strains was evaluated by disk diffusion method according to the Clinical and Laboratory Standards Institute document VET 01A4 (CLSI, 2013a). Criteria for interpretation of disk diffusion method described in CLSI document VET01-A4 were performed according to CLSI document VET 01-S2 (CLSI, 2013b). After isolation and identification, three to five colonies were transferred to a tube containing $3 \mathrm{~mL}$ of Mueller-Hinton broth and incubated at $37^{\circ} \mathrm{C}$ until cultures reached a standard turbidity of 0.5 , based on the McFarland scale. Using a sterile swab, contents of the tube were distributed on a $150-\mathrm{mm}$ plate containing Mueller-Hinton agar, and 10 equidistant paper discs containing antibiotics: $20 \mu \mathrm{g}$ amoxicillin $+10 \mu \mathrm{g}$ clavulanic acid, $30 \mu \mathrm{g}$ cephalexin, $5 \mu \mathrm{g}$ enrofloxacin, $10 \mu \mathrm{g}$ gentamicin, $1 \mu \mathrm{g}$ oxacillin, $10 \mu \mathrm{g}$ penicillin, $30 \mu \mathrm{g}$ tetracycline, and $1.25 \mathrm{~g} / 23.75 \mu \mathrm{g}$ trimethoprim-sulfamethoxazole $\left(\mathrm{DME}^{\circledR}\right.$ Laboratory, Araçatuba, São Paulo, Brazil). Antimicrobial selection was based on the CLSI (2013b) for staphylococci. After 16-18 h of incubation at $35^{\circ} \mathrm{C}$ for most treatments, and $24 \mathrm{~h}$ for oxacillin, the halos were measured using a millimeter ruler. Antibiotic sensitivity was classified as sensitive, intermediate, and resistant, depending on 
halo size following the CLSI standardization (CLSI, 2013b). The interpretation criteria are shown in table 1. Additionally, all strains were subjected to PCR analysis to screen for the presence of the mecA gene (MEHROTRA et al., 2000).

\section{RESULTS AND DISCUSSION}

In the present study, 44 of the isolated strains were confirmed as $S$. pseudintermedius. These strains were isolated from 31 dogs $(31 / 52-59.6 \%)$. Of the 44 strains, 13 were obtained from same dogs but different ears, that means, only one strain was obtained from each ear of the dogs. Six strains were susceptible to all antimicrobials tested. The percentage of $S$. pseudintermedius strain antimicrobial susceptibility is shown in table 2 . Table 3 shows the resistance pattern of the strains.

S. pseudintermedius was detected in almost $60 \%$ of dogs with otitis externa. This rate is higher than that reported in previous studies (LILENBAUM et al., 2000; HOEKSTRA \& PAULTON, 2002; PENNA et al., 2010; SAPUTRA et al., 2017). This variation in results might be due to geographical differences, and clinical conditions (with and/or without otitis), age, and breed of the dogs. In Brazil, studies examining otitis caused by $S$. pseudintermedius in dogs are scarce, making any comparison difficult. The isolation rate obtained in this study was greater than that reported by the two previously published studies in Brazil (LILENBAUM et al., 2000; PENNA et al., 2010). Taken together, our results indicated that $S$. pseudintermedius is an important bacterium causing otitis in dogs and should be considered when treating this disease.

High beta-lactam susceptibility rates were detected for some antibiotics, with $75 \%$ of the strains susceptible to cephalexin and $93.2 \%$ to amoxicillin plus clavulanic acid. In contrast, less than $23 \%$ of the strains were susceptible to penicillin. High susceptibility rates to amoxicillin plus clavulanic have been reported previously (PENNA et al., 2010;KROEMER et al., 2014; DE MARTINO et al., 2016). However, resistance to penicillin has not been previously reported ( LILENBAUM et al., 2000, KROEMER et al., 2014;; DE MARTINO et al., 2016). Cephalexin is used more commonly to treat pyoderma, a common infection caused by S. pseudintermedius. Since only first-generation cephalosporins, such as cephalexin, are suitable for oral usage, it is a common choice for most clinicians. Moreover, in veterinary dermatology, studies suggested that pathogenic staphylococci slowly acquired resistance to cephalosporins (MASON \& KIETZMANN, 1999), which may account for the high susceptibility to cephalexin detected in this study.

Owing to improve in vitro stability, oxacillin, a penicillinase-resistant semi-synthetic penicillin, is commonly used in veterinary microbiology laboratories to detect methicillin resistant staphylococci (COLE et al., 2006). While not routinely used for therapy, the inclusion of oxacillin in antibiogram tests is useful as methicillin-resistant staphylococci are commonly resistant to all beta-lactams, and to aminoglycosides, quinolones, macrolides, phenicols, sulfonamides, and tetracyclines (PAPICH, 2012). This pattern was observed in our study (Table 3). Here, resistance to oxacillin by disk diffusion was detected in 13 of 44 strains $(29,55 \%)$. However, PCR analysis for mecA revealed that seven out of the 13 strains classified as resistant to oxacillin by disk diffusion harbored the $m e c A$ gene and five strains that were positive for $m e c A$

Table 1 - Susceptibility test interpretive criteria for antibiotic against Staphylococcus spp. according to the Clinical and Laboratory Standards Institute document VET 01-S2 (CLSI, 2013).

\begin{tabular}{|c|c|c|c|}
\hline \multirow{2}{*}{ Antibiotic } & \multirow[b]{2}{*}{ Susceptible } & \multirow[b]{2}{*}{ Intermediate } & \multirow[b]{2}{*}{ Resistant } \\
\hline & & & \\
\hline Amoxicillin-clavulanic acid & $>20$ & - & $\leq 19$ \\
\hline Cephalexin $^{*}$ & $\geq 18$ & $15-17$ & $\leq 14$ \\
\hline Enrofloxacin & $\geq 23$ & $17-22$ & $\leq 16$ \\
\hline Gentamicin $^{* *}$ & $\geq 15$ & $13-14$ & $\leq 12$ \\
\hline Oxacillin $^{* * *}$ & $\geq 17$ & - & $\leq 18$ \\
\hline Penicillin & $\geq 29$ & - & $\leq 28$ \\
\hline Tetracycline & $\geq 19$ & $15-18$ & $\leq 14$ \\
\hline Trimethoprim-sulfamethoxazole ${ }^{* *}$ & $\geq 16$ & $11-15$ & $\leq 10$ \\
\hline
\end{tabular}

${ }^{*}$ Zone diameter interpretative standards for cephalotin. ${ }^{* *}$ Human-derived zone diameter interpretative standards for veterinary pathogens. ${ }^{* * *}$ Zone diameter interpretative standards for S. pseudintermedius. 
Table 2 - Percentages of antimicrobial resistance in S. pseudintermedius (SP) isolated from dogs $(\mathrm{n}=44)$ with external otitis in Brazil, as determined by disk diffusion method.

\begin{tabular}{lccccccc}
\hline AMO & CFE & GEN & OXA & ENO & PEN & SUT & TET \\
\hline $6.8 \%$ & $25 \%$ & $27.3 \%$ & $29.6 \%$ & $38.6 \%$ & $77.3 \%$ & $63.6 \%$ & $61.4 \%$ \\
\hline
\end{tabular}

AMO, Amoxicillin+clavulanic acid; CFE, cephalexin; ENO, enrofloxacin; GEN, gentamicin; OXA, oxacillin; PEN, penicillin; SUT, trimethoprim-sulfamethoxazole; TET, tetracycline.

gene in the PCR were susceptible to oxacillin by disk diffusion. That means that a total of $12(27.3 \%)$ strains tested positive for mecA by PCR. If we consider both in vitro and PCR results, a total of 18 (40, 9\%) strains were classified as MRSP. Discrepancies in the results obtained by the disk diffusion test and PCR detection of $m e c A$ has been previously reported (ELHASSAN et al., 2015; BOURGUIGNON et al., 2016). Although, $m e c A$ seems to be the most common gene associated with meticillin resistance in $S$. pseudintermedius, some studies have shown that another gene $(\mathrm{mecC})$ could also be responsible for this resistance profile (KJELLMAN et al., 2015). This could explain the absence of mec $A$ in some of the strains that were resistant to oxacillin in the present study.

Table 3 - Resistance pattern of Staphylococcus pseudintermedius strains isolated from otitis externa in dogs.

\begin{tabular}{lc}
\hline Antimicrobial resistance Pattern & $\begin{array}{c}\text { Number of } \\
\text { strains }\end{array}$ \\
\hline AMO CFE ENO GEN OXA PEN SUT TET & 6 \\
AMO CFE ENO OXA PEN SUT TET & 3 \\
AMO ENO OXA PEN SUT TET & 1 \\
AMO CFE PEN TET & 1 \\
ENO GEN PEN SUT TET & 2 \\
ENO PEN SUT TET & 2 \\
ENO PEN SUT & 1 \\
ENO PEN & 1 \\
ENO TET & 2 \\
GEN PEN SUT TET & 2 \\
GEN PEN & 1 \\
OXA PEN TET & 1 \\
PEN SUT TET & 7 \\
PEN SUT & 2 \\
PEN TET & 1 \\
OXA & 1 \\
PEN & 3 \\
SUT & 1 \\
Susceptible strains & 6 \\
Total & 44 \\
\hline
\end{tabular}

AMO, Amoxicillin+clavulanic acid; CFE, cephalexin; ENO, enrofloxacin;; GEN, gentamicin; OXA, oxacillin; PEN, penicillin; SUT, trimethoprim-sulfamethoxazole; TET, tetracycline.
For non-beta-lactam antimicrobials, 63.6\% of the strains showed resistance to sulfamethoxazoletrimethoprim, $61.4 \%$ to tetracycline and $38,64 \%$ to enrofloxacin. Aminoglycoside resistance was observed in 27.3 of strains for gentamicin. Previous studies have shown that resistance to aminoglycosides is commonly high (PENNA et al., 2010; DE MARTINO et al., 2016).

Resistance to sulfamethoxazole-trimethoprim was also reported in other studies (LILENBAUM et al., 2000; DE MARTINO et al., 2016). However, a survey in Europe revealed that sensitivity to sulfonamides was very high $(>90.0 \%)$. Similar resistance rates were observed for tetracycline in Italy (DE MARTINO et al., 2016). One study in Brazil reported that more than $90 \%$ of staphylococci strains were sensitive to tetracycline (LILENBAUM et al., 2000). Reports of enrofloxacin resistance described similar results (PENNA et al., 2010; DE MARTINO et al., 2016), while in Europe the level of susceptibility to fluoroquinolones has been reported as over 90\% (KROEMER et al., 2014).

Recent studies have shown that MRSP is responsible for healthcare-associated infections in companion animals (WALTHER et al., 2017). In addition to canine health problems, MRSP infection is increasing in humans, especially those with close relationships with dogs (SOMAYAJI et al., 2016; ROBB et al., 2017) Furthermore, antimicrobial resistance surveillance to inform evidence-based empiric therapeutic selection suggested that a new clonal population of MRSP, resistant to most therapeutically antibiotics, is emerging (PRIYANTHA; GAUNT \& RUBIN, 2016; VIDELA, 2017). According to KASAI et al. (2016), the incidence of MRSP has been increasing worldwide, limiting treatment options.

Sulfamethoxazole-trimethoprim, tetracycline, and penicillin had the highest resistance rates in this study. While statistics concerning the veterinary antibiotic market in Brazil are not available, data from the USA and all European Union countries showed that tetracycline is the most sold antimicrobial followed by penicillin and sulfonamides (FDA, 2014; EMA, 2015). Therefore, resistance to these compounds is of great clinical importance, as 
they are frequently used in the treatment of human infections (GUPTA et al., 2011).

It is also interesting to note that 26 (59, $1 \%$ ) strains were resistant to three or more classes of antimicrobials, classifying them as multi resistant isolates. This rate is higher than that in a previous report examining staphylococci isolated from otitis in Brazil (LILENBAUM et al., 2000). However, recently studies in Brazil, and other countries, have reported high multi resistance rates of staphylococci group isolates (PENNA et al., 2009; DE MARTINO et al., 2016), emphasizing the emergency of SP resistance.

Antimicrobial agents are indispensable for decreasing mortality and morbidity associated with infectious diseases in animals and humans. In veterinary medicine, they have been used for therapy, metaphylaxis, prophylaxis, and growth promotion (SCHWARZ et al, 2001). Recent studies on $S$. pseudintermedius have shown a significant increasing temporal trend in resistance to several antibiotics (PRIVANTHA et al., 2016; QEKWANA 2017a,b). Our results are consistent with those of these reports and highlighted the emergence of antimicrobial resistance in $S$. pseudintermedius, imposing a great challenge for antimicrobial therapy in animals (PRIYANTHA et al., 2016).

Despite the increasing importance of MRSP in veterinary medicine, and for humans, there is a lack of studies concerning MRSP in Brazil. Here, we observed a high isolation frequency of $S$. pseudintermedius from dogs with otitis. Additionally, half of the isolates were classified as MRSP, and almost $60 \%$ were multi resistant. This study highlighted the need for increased surveillance of antibiotic resistance in veterinary settings in Brazil.

\section{BIOETHICS AND BIOSSECURITY COMMITTEE APPROVAL}

This experiment was approved by the Comitê de Ética em Uso Animal of Universidade Federal de Minas Gerais (UFMG) under protocol number 246/2013.

\section{ACKNOWLEDGEMENTS}

The authors would like to thank the Pró Reitoria de Pesquisa da Universidade Federal de Minas Gerais (PRPq/UFMG) for the support.

\section{DECLARATION OF CONFLICTING INTERESTS}

The authors declared no potential conflicts of interest with respect to the research, authorship, and/or publication of this article.

\section{REFERENCES}

BANNOEHR, J. et al. Molecular diagnostic identification of Staphylococcus pseudintermedius. Journal of Clinical Microbiology, v. 47, n. 2, p. 469-471, 2009. Available from: <http://jcm.asm.org/ content/47/2/469.full>. Acessed: Mar. 12, 2018.

BANNOEHR, J.; GUARDABASSI,L.Staphylococcuspseudintermedius in the dog: Taxonomy, diagnostics, ecology, epidemiology and pathogenicity. Veterinary Dermatology, v. 23, n. 4, p. 1-16, 2012. Available from: <http://onlinelibrary.wiley.com/doi/10.1111/j.13653164.2012.01046.x/epdf $>$. Accessed: Aug. 11, 2017.

BOTONI, L. S. et al. Prevalence and in vitro susceptibility of methicillin-resistant Staphylococcus pseudintermedius (MRSP) from skin and nostrils of dogs with superficial pyoderma. Pesquisa Veterinaria Brasileira, v. 36, n. 12, p. 1178-1180, 2016. Available from: <http://www.scielo.br/pdf/pvb/v36n12/1678-5150pvb-36-12-01178.pdf $>$. Accessed: Aug. 11, 2017.

BOURGUIGNON, E. et al. Description of methicillin-resistant Staphylococcus pseudintermedius from canine pyoderma in Minas Gerais state, Brazil. Arquivos Brasileiros de Medicina Veterinária e Zootecnia, v. 68, n. 2, p. 299-306, 2016. Available from: <http:// www.scielo.br/pdf/abmvz/v68n2/0102-0935-abmvz-68-02-00299. pdf $>$. Accessed: Aug. 11, 2017.

CLSI. Performance standards for antimicrobial disk and dilution suscetibility tests for bacteria isolated from animals; Aproved standard. Fourth edition. CLSI document VET01-A4. Clinical and Laboratory Standards Institute. 33 (7), VET01-A4, 2013a.

CLSI. Performance standards for antimicrobial disk and dilution suscetibility tests for bacteria isolated from animals. Second informational supplement. CLSI document VET01-S2. Clinical and Laboratory Standards Institute. 33 (8), VET01-S2, 2013b.

COLE, L. K. et al. Short communications staphylococci in dogs with end-stage otitis. Veterinary Record, v. 159, p. 418-419, 2006. Available from: $<$ http://veterinaryrecord.bmj.com/content/ vetrec/159/13/418.full.pdf $>$. Accessed: Aug. 11, 2017.

DE MARTINO, L. et al. An update on microbiological causes of canine otitis externa in Campania Region, Italy. Asian Pacific Journal of Tropical Biomedicine, v. 6, n. 5, p. 384-389, 2016. Available from: $<$ http://veterinaryrecord.bmj.com/content/vetrec/159/13/418.full. pdf $>$. Accessed: Aug. 11, 2017.

ELHASSAN et al. Absence of the mecA Gene in methicillin resistant Staphylococcus aureus isolated from different clinical specimens in Shendi City, Sudan. BioMed Research International, v. 2015, Article ID 895860, 5 pages, 2015. Available from: $<$ https://www. hindawi.com/journals/bmri/2015/895860/cta/>. Accessed: Aug. $11,2017$.

EMA. European Medicines Agency, European Surveillance of Veterinary Antimicrobial Consumption, 2015. Sales of veterinary antimicrobial agents in 26 EU/EEA countries in 2013. (EMA/387934/2015). Available from: <http://www. ema.europa.eu/docs/en_GB/document_library/Report/2015/10/ WC500195687.pdf>. Accessed: Aug. 11, 2017.

FDA. 2010. Summary report on antimicrobials sold or distributed for use in food-producing animals: food and drug 
administration. 2014. Available from: <https://www.fda.gov/ downloads/ForIndustry/UserFees/AnimalDrugUserFeeActADUFA/ ucm277657.pdf>. Accessed: Aug. 11, 2017.

FRANK, L. A.; LOEFFLER, A. Meticillin-resistant Staphylococcus pseudintermedius: Clinical challenge and treatment options. Veterinary Dermatology, v. 23, n. 4, 2012. Available from: <http:// onlinelibrary.wiley.com/doi/10.1111/j.1365-3164.2012.01047.x/ epdf $>$. Accessed: Aug. 11, 2017.

GUPTA, K. et al. Soper. International clinical practice guidelines for the treatment of acute uncomplicated cystitis and pyelonephritis in women: A 2010. Update by the Infectious Diseases Society of America and the European Society for Microbiology and Infectious Diseases. Clinical Practice Guidelines d CID. Clinical Infectious Diseases, v.52, 2011. Available from: <https:/academic.oup.com/cid/ article-lookup/doi/10.1093/cid/ciq257>. Accessed: Aug. 11, 2017.

HOEKSTRA, K.A., PAULTON, R.J. Clinical prevalence and antimicrobial susceptibility of Staphylococcus aureus and Staph. intermedius in dogs. Journal Applied Microbiology, v.93, p. 406-13, 2002. Available from: <http://onlinelibrary.wiley.com/doi/10.1046/ j.1365-2672.2002.01708.x/epdf>. Accessed: Aug. 11, 2017.

KANIA, S. A. et al. Methicillin resistance of staphylococci isolated from the skin of dogs with pyoderma. American Journal of Veterinary Research, v. 65, n. 9, p. 1265-1268, 2004. Available from: $<$ https://www.ncbi.nlm.nih.gov/pubmed/15478775>. Accessed: Aug. 11, 2017.

KASAI, T. et al. New categories designated as healthcare-associated and community-associated methicillin-resistant Staphylococcus Pseudintermedius in Dogs. Microbiology and Immunology, v.60, p. 540-551, 2016. Available from: <http://onlinelibrary.wiley.com/ doi/10.1111/1348-0421.12401/pdf>. Accessed: Aug. 11, 2017.

KROEMER, S. et al. Comparative immunology, microbiology and infectious diseases antibiotic susceptibility of bacteria isolated from infections in cats and dogs throughout Europe (2002 - 2009). Comparative Immunology, Microbiology and Infectious Diseases, v. 37, n. 2, p. 97-108, 2014. Available from: <http:// www.sciencedirect.com/science/article/pii/S0147957113000775/ pdfft?md5=c73ed48b947f410b5531 dbcde9817363\&pid=1-s2.0S0147957113000775-main.pdf>. Accessed: Aug. 11, 2017.

LILENBAUM, W. et al. Antimicrobial susceptibility of staphylococci isolated from otitis externa in dogs. Letters in applied microbiology, v. 31 , n. 1, p. 42-45, 2000. Available from: <http:// onlinelibrary.wiley.com/doi/10.1046/j.1472-765x.2000.00759.x/ epdf>. Accessed: Aug. 11, 2017.

LOPES, G.V. et al. Methicillin-resistant Staphylococcus pseudintermedius clonal groups isolated from canine pyoderma in Brazil. Acta Scientiae Veterinariae, v.43, p.1138, 2015. Available from: <http://revistas.bvs-vet.org.br/actascivet/article/ view/35417/39822>. Accessed: Aug. 11, 2017.

MASON, I. S.; KIETZMANN, M. Cephalosporins - pharmacological basis of clinical use in veterinary dermatology. Veterinary Dermatology, v. 10, p. 187-192, 1999. Available from: <http:// onlinelibrary.wiley.com/doi/10.1046/j.1365-3164.1999.00183.x/ epdf>. Accessed: Aug. 11, 2017.

MEHROTRA, M.; WANG, G.; JOHNSON, W. M. Multiplex PCR for detection of genes for Staphylococcus aureus enterotoxins, exfoliative toxins, toxic shock syndrome toxin 1 , and methicillin resistance. Journal of Clinical Microbiology, v. 38 , n. 3, p. $1032-1035,2000$. Available from: $<$ https://www. ncbi.nlm.nih.gov/pmc/articles/PMC86330/pdf/jm001032.pdf>. Accessed: Aug. 11, 2017.

PAPICH, M. G. Selection of antibiotics for meticillin-resistant Staphylococcus pseudintermedius: Time to revisit some old drugs. Veterinary Dermatology, v. 23, n. 4, p. 1-10, 2012. Available from: $<$ http://onlinelibrary.wiley.com/doi/10.1111/j.1365-3164.2011.01030.x/ epdf $>$. Accessed: Aug. 11, 2017.

PENNA, B. et al. Species distribution and antimicrobial susceptibility of staphylococci isolated from canine otitis externa. Veterinary Dermatology, v. 21, n. 3, p. 292-296, 2010. Available from: <http:// onlinelibrary.wiley.com/doi/10.1111/j.1365-3164.2009.00842.x/ epdf $>$. Accessed: Aug. 11, 2017.

PRIYANTHA, R.; GAUNT, M. C.; RUBIN, J. E. Antimicrobial susceptibility of Staphylococcus pseudintermedius colonizing healthy dogs in Saskatoon, Canada. Canadian Veterinary Journal, v. 57, n. 1, p. 65-69, 2016. Available from: <https://www.ncbi.nlm. nih.gov/pmc/articles/PMC4677612/ >. Accessed: Aug. 11, 2017.

QEKWANA, D.N. et al. Burden and predictors of Staphylococcus aureus and $\boldsymbol{S}$. pseudintermedius infections among dogs presented at an academic veterinary hospital in South Africa (2007-2012). PeerJ, v.5, e3198, 2017a. Available from: <https://www.ncbi. nlm.nih.gov/pmc/articles/PMC5392248/pdf/peerj-05-3198.pdf>. Accessed: Aug. 11, 2017.

QEKWANA, D.N. et al. Patterns and predictors of antimicrobial resistance among Staphylococcus spp. from canine clinical cases presented at a veterinary academic hospital in South Africa. BMC Veterinary Research, v.13, p.116, 2017b. Available from: <https:/www.ncbi.nlm.nih.gov/pmc/articles/ PMC5410067/pdf/12917 2017 Article 1034.pdf>. Accessed: Aug. 11, 2017.

ROBB, A.R. et al. Skin infection caused by a novel strain of Staphylococcus pseudintermedius in a Siberian husky dog owner. JMM Case Reports, v.20, jmmcr005087, 2017. Available from: $<$ https:/www.ncbi.nlm.nih.gov/pmc/articles/PMC5382809/pdf/ jmmcr-4-5087.pdf $>$. Accessed: Aug. 11, 2017.

ROBERTS, A.L. Identification of Staphylococcus epidermidis in the clinical microbiology laboratory by molecular methods. Methods in Molecular Biology, v.33, p.53, 2014. Available from: <https:// link.springer.com/protocol/10.1007\%2F978-1-62703-736-5_3>. Accessed: Aug. 11, 2017.

SANCHEZ, R. et al. Aislamiento bacteriano en casos de otitis canina y su susceptibilidad antibiotica. Revista de Investigaciones Veterinarias del Peru, v. 22, n. 2, p. 161-166, 2011. Available from: <http://www.scielo.org.pe/pdf/rivep/v22n2/a13v22n2.pdf>. Accessed: Aug. 11, 2017.

SAPUTRA, S. et al. Antimicrobial resistance in coagulase-positive staphylococci isolated from companion animals in Australia: A one year study. PLoS One, v.12, e0176379, 2017. Available from: $<$ http://journals.plos.org/plosone/article/file?id=10.1371/journal. pone. $0176379 \&$ type $=$ printable $>$. Accessed: Aug. 11, 2017.

SASAKI, T. et al. Multiplex-PCR method for species identification of coagulase-positive staphylococci. Journal of Clinical Microbiology, v. 48, n. 3, p. 765-769, 2010. Available from: $<$ https://www.ncbi.nlm.nih.gov/pmc/articles/PMC2832457/>. Accessed: Aug. 11, 2017. 
SCHWARZ, S.; KEHRENBERG, C.; WALSH, T. R. Use of antimicrobial agents in veterinary medicine and food animal production. International Journal of Antimicrobial Agents, v. 17, p. 431-437, 2001. Available from: <http://www. sciencedirect.com/science/article/pii/S0924857901002977/ pdfft? $\mathrm{md} 5=89 \mathrm{f} 7 \mathrm{~d} 132 \mathrm{a} 8 \mathrm{e} 7 \mathrm{da} 1745 \mathrm{f} 82848857 \mathrm{a} 0510 \& \mathrm{pid}=1-$ s2.0-S0924857901002977-main.pdf $>$. Accessed: Aug. 11, 2017.

SOMAYAJI, R. et al. Human infections due to Staphylococcus pseudintermedius, an emerging zoonosis of canine origin: report of 24 cases. Diagnostic Microbiology and Infectious Disease, v. 85, n. 4, p. 471-476, 2016. Available from: $\quad<$ http://www.sciencedirect.com/science/article/pii/ S0732889316301304/pdfft?md5=aa10d78e16a4afc 985586 dcb5fef071 f\&pid=1-s2.0-S0732889316301304-main.pdf $>$. Accessed: Aug. 11, 2017.
VIDELA, R. et al. Clonal complexes and antimicrobial susceptibility profiles of Staphylococcus pseudintermedius isolates from dogs in the United States. Microbial Drug Resistance. Ahead of print, 2017. doi: $10.1089 / \mathrm{mdr} 2016.0250$. Available from: $<$ https://www. ncbi.nlm.nih.gov/pubmed/28504897>. Accessed: Aug. 11, 2017.

VANDUIJKEREN,E. etal. Review onmethicillin-resistantStaphylococcus pseudintermedius. Journal of Antimicrobial Chemotherapy, v. 66, n. 12, p. 2705-2714, 2011. Available from: $<$ https://academic.oup.com/jac/articlelookup/doi/10.1093/jac/dkr367>. Accessed: Aug. 11, 2017.

WALTHER, B. et al. Multidrug-resistant opportunistic pathogens challenging veterinary infection control, Veterinary Microbiology, v. 200, p. 71-8, 2017. Available from: <http://www.sciencedirect. com/science/article/pii/S0378113516301419/pdfft?md5=cffe $67 \mathrm{af}$ d3b9d460504d0984923cfebe\&pid=1-s2.0-S0378113516301419. main.pdf>. Accessed: Aug. 11, 2017. 